\title{
FINANCIAL PERFORMANCE IN VALUE IN THE AUTOMOTIVE SECTOR AND COMPONENTS GO PUBLIC IN INDONESIA
}

\author{
Herdiyana \\ Dosen Tetap Fakultas Ekonomi Universitas Pakuan \\ Nelly Setiawan \\ Mahasiswa Fakultas Ekonomi Universitas Pakuan
}

\begin{abstract}
ABSTRAK
Penelitian ini bertujuan untuk mengetahui pengaruh nilai kinerja keuangan perusahaan secara bersama-sama. Kinerja keuangan diukur dengan menggunakan Total Debt to Equity Ratio Total (DER), Total Debt to Total Asset Ratio (DAR), Net Profit Margin (NPM) dan Return on Assets (ROA). Jangka waktu penelitiandari 2009-2013. Metode analisis yang digunakan adalah analisis kuantitatif dengan menggunakan analisis regresi linier berganda. Penelitian ini menyatakan bahwa uji t menunjukkan DER dan DAR tidak berpengaruh pada nilai perusahaan, tetapi ROA t hitung > t tabel $(-3.233<-1,697)$ dengan signifikansi 0,003 <0,05 dan NPM t $>\mathrm{t}$ tabel $(2.788>1,697)$ dengan signifikansi $0,009<0,05$ sehingga dapat meramalkan nilai perusahaan ROA dan NPM (Price to Book value) yang tepat. Sementara pengujian hipotesis menggunakan uji $\mathrm{F}$ menunjukkan bahwa DER, DAR, ROA, dan NPM secara simultan atau bersama-sama mempengaruhi nilai perusahaan (Price to Book value), karena nilai $\mathrm{F}$ hitung> F tabel (3.827> 2,69) dengan signifikansi 0,013<0,05. koefisien determinasi (R Square) dari 0338 ATAU 33,8\% hasil ini menunjukkan bahwa variasi Price to Book value (PBV) dapat dijelaskan oleh nilai DER, DAR, ROA, dan NPM 33,8\% sedangkan sisanya 66,2\% (100\% - 33,8\%) dijelaskan oleh variabel lain yang tidak termasuk dalam model.
\end{abstract}

Kata kunci: DER, DAR, ROA, NPM, and Price to Book Value.

\begin{abstract}
This study aims to determine the effect on the value of the company's financial performance simultaneously / together. Financial performance measured using the Total Debt to Equity Ratio Total (DER), Total Debt to Total Assets Ratio (DAR), Net Profit Margin (NPM) and Return on Assets (ROA). The period of 5 years of research carried out during the design year 2009-2013.The study consists of types, methods, and techniques of research. This type of research is the verification, the method used is survey explanatory, and engineering studies using inferential statistics. The analytical method used is quantitative analysis using an analysis tool multiple linear regression analysis. For linear regression models obtained better then used the classical assumptions. Classic assumption test including normality test used, multicollinearity, heteroscedasticity test and autocorrelation test. This study states that: "The hypothesis testing using t test showed that the DER and DAR has no effect on the value of the company, but $R O A t>t$ table $(-3,233<-1.697)$ with significance $0.003<0.05$ and NPM $t>t$ table $(2,788>1.697)$ with significance $0.009<0.05$ so the predicted effects the value of the company ROA and NPM (Price to Book Value) is right. While testing the hypothesis using the F test showed that the DER, DAR, ROA, and NPM simultaneously or together affect the value of the company (Price to Book Value), because the value of $F$ count $>F$ table $(3,827>2,69)$ with significance $0.013<0.05$. The coefficient of determination $(R$ Square) of 0,338 atau 33,8\%. These results show that the variation of Price to Book Value (PBV) can be explained by the value of DER, DAR, ROA, and NPM 33.8\% while the remaining $66.2 \%(100 \%-33.8 \%)$ is explained by other variables not included in the model Here you are.
\end{abstract}

Keywords: DER, DAR, ROA, NPM, and Price to Book Value. 


\section{Pendahuluan}

Perekonomian Indonesia terlihat semakin berkembang. Menurut Ketua Gabungan Industri Kendaraan Bermotor Indonesia (Gaikindo), Sudirman MR, mengatakan pertumbuhan industri otomotif nasional mengalami kemajuan yang dapat dibanggakan sejak 2006 hingga sekarang. Pada 2010, angkanya kembali naik lebih dari 50 persen menjadi 764.000, dan terus naik pada 2011 ke angka 894.000 atau meningkat 19 persen. Kemudian, pada 2012 menyentuh angka 1,16 juta atau naik 24 persen. Hingga 2013 penjualan mencapai 1,2 juta unit atau naik 10,2 persen dan menjadi penjualan tertinggi sepanjang sejarah (www.jpnn.com).

Penjualan yang tinggi itu dianggap sebagai hal yang baik untuk investor karena investor akan tertarik pertumbuhan. Semakin tinggi tingkat penjualan maka semakin tinggi nilai perusahaan. Karena penjualan akan mempengaruhi laba di suatu perusahaan (Brigham Houstan, 2010:146). Perusahaan yang dipandang baik oleh investor yaitu artinya perusahaan dengan laba dan arus kas yang aman serta mengalami pertumbuhan penjualan dengan rasio Price Book Value yang lebih tinggi dibanding perusahaan dengan pengembalian yang rendah. Jika suatu perusahaan menerima tingkat pengembalian atas aset yang rendah, maka rasio Price Book Value- nya akan relatif rendah dibandingkan rata-rata perusahaan lain (Brigham Houstan, 2010:151).

Menurut Hartono (2000:79) terdapat tiga jenis penilaian pada perusahaan yang berhubungan dengan saham, yaitu nilai buku (Book Value), nilai pasar (Market Value) dan nilai intrinsik (Intrinsic Value). Investor perlu mengetahui dan memahami ketiga nilai tersebut sebagai informasi penting dalam pengambilan keputusan invetasi saham karena dapat membantu investor untuk mengetahui saham mana yang bertumbuh dan murah. Salah satu pendekatan dalam menentukan nilai pasar adalah Price Book Value (PBV).

Price Book Value (PBV) adalah salah satu ukuran dari rasio penilaian yang paling komprehenship untuk menilai perusahaan seperti rasio nilai pasar terhadap nilai buku saham. Harga rasio penilaian ini mencerminkan rasio resiko (rasio likuiditas dan rasio solvabilitas), ratio pengembalian (rasio aktivitas, rasio profitabilitas, dan rasio pertumbuhan). Price Book Ratio (PBV) memiliki tujuan untuk memaksimalkan nilai perusahaan dan para investor (Zulian Yamit, 2007:4).

Rasio likuiditas, solvabilitas dan profitabilitas merupakan alat ukur kinerja keuangan dengan menggunakan rasio keuangan (Harahap, 2013:301). Menurut Brigham Houston (2010:133) Rasio keuangan dirancang untuk membantu kita mengevaluasi laporan keuangan. Salah satu tujuan rasio keuangan untuk memahami posisi keuangan perusahaan masa lalu dan masa sekarang dari aspek waktu tertentu : likuiditas, solvabilitas, profitabilitas, dll (Artur J.Keown, Jhon D.Martin, J.William Petty, David F.Scott, 2008:74).

Rasio solvabilitas atau disebut dengan rasio leverage yaitu mengukur seberapa besar perusahaan dibiayai dengan utang. Penggunaan utang yang terlalu tinggi akan membahayakan perusahaan karena perusahaan akan masuk dalam kategori Extreme Leverage (utang ekstrem) yaitu perusahaan terjebak dalam tingkat utang yang tinggi dan sulit untuk melepaskan beban utang tersebut. Karena itu sebaiknya perusahaan harus menyeimbangkan berapa utang yang layak diambil dan dari mana sumber-sumber yang dapat dipakai untuk membayar utang (Irham 
Fahmi, 2012:127). Penggunaan hutang yang tinggi juga dapat menurunkan nilai perusahaan karena adanya kemungkinan timbulnya biaya kepailitan dan biaya keagenan (Weston dan Copeland, 1996:53). Rasio solvabilitas terdiri dari Debt to Equity Ratio (DER) dan Debt to Asset Ratio (DAR).

Debt to Equity Ratio (DER) menurut Joel G.Siegel dan Jae K. Shim (Hlm. 128) mendifinisikannya sebagai "Ukuran yang dipakai dalam menganalisis laporan keuangan untuk memperlihatkan besarnya jaminan yang tersedia untuk kreditor". Dalam persoalan Debt To Equity Ratio ini yang perlu dipahami bahwa, tidak ada batasan berapa Debt To Equity Ratio (DER) yang aman bagi suatu perusahaan, namun untuk konservatif biasanya Debt To Equity Ratio yang lewat $66 \%$ atau $2 / 3$ sudah dianggap beresiko (www.esamuel.com, 2004).

Selain Debt to Equity Ratio (DER) dapat menggunakan Debt to Asset Ratio (DAR). Menurut Harahap (2013:304) DAR menunjukkan sejauhmana utang dapat ditutupi oleh aktiva lebih besar rasionya lebih aman (solvable). Bisa juga dibaca berapa porsi utang dibanding dengan aktiva. Supaya aman porsi utang terhadap aktiva harus lebih kecil.

Selain dilihat dari solvabilitasnya, perusahaan pun harus dilihat dari segi profitabilitasnya. Analisis profitabilitas atau dikenal dengan rasio profitabilitas yang merupakan bagian dari rasio keuangan adalah rasio yang mengukur efektifitas manajemen secara keseluruhan yang ditujukan oleh besar kecilnya tingkat keuntungan yang diperoleh dalam hubungannya dengan penjualan maupun investasi. Semakin baik rasio profitabilitas maka semakin baik menggambarkan kemampuan tingginya perolehan keuntungan perusahaan (Irham Fahmi, 2012:135). Menurut Kasmir (2008:196) Rasio profitabilitas merupakan rasio untuk menilai kemampuan perusahaan dalam mencari keuntungan. Rasio ini juga memberikan ukuran tingkat efektivitas manajemen suatu perusahaan. Keberhasilan perusahaan dalam menghasilkan laba akan terlihat dalam rasio ini, semakin tinggi rasio ini berarti semakin tinggi laba yang dihasilkan oleh perusahaan. Tingginya laba yang dihasilkan perusahaan mencerminkan bahwa perusahaan mempunyai prospek yang baik kedepannya. Perusahaan dengan prospek yang baik ini yang diinginkan oleh investor dan investor lebih tertarik untuk membeli saham. Semakin tinggi permintaan dari investor terhadap saham maka akan mempengaruhi harga saham dan akan meningkat nilai perusahaan. Sehingga semakin tinggi profitabilitas perusahaan maka akan semakin tinggi nilai perusahaan. Rasio profitabilitas terdiri dari Return On Asset (ROA) dan Net Profit Margin (NPM).

Menurut Suad Husnan dan Enny Pudjiastuti (2012:76) Return On Asset (ROA) menunjukkan berapa banyak laba bersih setelah pajak dapat dihasilkan dari (rata-rata) seluruh kekayaan yang dimiliki perusahaan. Karena itu digunakan angka laba setelah pajak sebagai pembilang. Menurut Brigham Houstan (2010:152) jika suatu perusahaan menerima ROA yang rendah, maka PBV-nya akan relatif lebih rendah.

Selain Return On Asset (ROA) dapat diukur dengan Net Profit Margin (NPM). Menurut Harahap (2013:304) Net Profit Margin (NPM) menunjukkan berapa besar presentase pendapatan bersih yang diperoleh dari setiap penjualan. Semakin besar rasio ini semakin baik karena dianggap kemampuan perusahaan dalam mendapatkan laba cukup tinggi. Menurut Dwi Prastowo dan Rifka Julianty (2008:96) Net Profit Margin (NPM) 
dapat memberikan informasi yang berharga mengenai struktur biaya dan laba perusahaan, serta memungkinkan para analis untuk melihat sumber efisiensi dan ketidakefisienan perusahaan.

Price Book Value (PBV) menunjukkan bahwa nilai perusahaan melebihi $93 \%$ dari apa yang telah dan sedang ditanamkan oleh pemilik perusahaan. Semakin tinggi rasio ini, semakin besar tambahan wealth yang dinikmati oleh pemilik perusahaan (Suad Husnan dan Enny Pudjiastuti, 2012:78).

Berikut ini adalah Price Book Value (PBV) Pada Sektor Otomotif Dan Komponen Di Bursa Efek Indonesia Periode 2009-2013.

Tabel 1.

Rata-rata Price Book Value (PBV) dan Perubahannya setiap tahun Pada Sektor Otomotif Dan Komponen Periode 2009-2013

\begin{tabular}{|c|c|c|c|c|c|c|c|c|c|}
\hline \multirow[b]{2}{*}{ Emiten } & \multicolumn{5}{|c|}{ PBV } & \multicolumn{4}{|c|}{$\triangle P B V$} \\
\hline & Tahun 2009 & Tahun 2010 & Tahun 2011 & Tahun 2012 & Tahun 2013 & $\Delta 2009-2010$ & $\Delta 2010-2011$ & $\Delta$ 2011-2012 & $\Delta 2012-2013$ \\
\hline 1.ASII & 0,35 & 3,43 & 3,95 & 3,43 & 2,59 & 8,73 & 0,15 & $-0,52$ & $-0,24$ \\
\hline 2.AUT0 & 0,27 & 2,60 & 2,78 & 2,60 & 1,84 & 8,81 & 0,07 & $-0,17$ & $-0,29$ \\
\hline 3.BRAM & 0,66 & 2,65 & 2,92 & 2,65 & 2,76 & 2,99 & 0,10 & $-0,27$ & 0,04 \\
\hline 4.GDYR & 1,05 & 0,78 & 0,87 & 0,78 & 0,73 & $-0,26$ & 0,12 & $-0,09$ & $-0,06$ \\
\hline 5.GJTL & 0,55 & 1,42 & 2,33 & 1,42 & 1,02 & 1,55 & 0,65 & $-0,92$ & $-0,28$ \\
\hline 6.IMAS & 0,10 & 2,57 & 0,35 & 2,57 & 2,03 & 25,39 & $-0,86$ & 2,22 & $-0,21$ \\
\hline 7.INDS & 0,05 & 1,16 & 1,25 & 1,16 & 0,80 & 20,87 & 0,07 & $-0,08$ & $-0,31$ \\
\hline 8.LPIN & 0,25 & 1,21 & 0,40 & 1,21 & 0,74 & 3,79 & $-0,67$ & 0,81 & $-0,39$ \\
\hline 9.MASA & 0,86 & 1,11 & 1,73 & 1,11 & 0,95 & 0,29 & 0,56 & $-0,62$ & $-0,14$ \\
\hline 10.NIPS & 0,01 & 0,38 & 0,48 & 0,38 & 1,05 & 59,57 & 0,26 & $-0,10$ & 1,74 \\
\hline 11.PRAS & 0,57 & 0,53 & 0,32 & 0,53 & 0,32 & $-0,06$ & $-0,39$ & 0,21 & $-0,40$ \\
\hline 12.SMSM & 2,17 & 4,43 & 2,50 & 4,43 & 4,92 & 1,04 & $-0,44$ & 1,93 & 0,11 \\
\hline Rata-Rata & 0,57 & 1,86 & 1,66 & 1,86 & 1,65 & 2,23 & $-0,11$ & 0,20 & $-0,04$ \\
\hline
\end{tabular}

Sumber : $\underline{w w w . i d x . c o m}$, data diolah dari laporan keuangan

Berdasarkan data pada tabel 5 . dapat dilihat bahwa Rata-rata Price Book Value (PBV) dan Perubahannya Pada Sektor Otomotif Dan Komponen periode 2009-2010 mengalami fluktuatif. Pada tahun 2009-2010 mengalami kenaikan sebesar 2,23. Penurunan terjadi pada tahun 2010-2011 sebesar -0,11. Pada tahun 2011-2012 mengalami kenaikan sebesar 0,20 dan tahun 2012-2013 turun sebesar -0,04. Namun pada perusahaan yang diteliti kenaikan DER yang semakin besar diikuti dengan penurunan yang signifikan oleh Price Book Value, sedangkan penurunan DAR yang semakin besar diikuti dengan kenaikan yang signifikan oleh Price Book Value.
Kemudian pada perusahaan yang diteliti penurunan ROA semakin besar diikuti dengan penurunan yang signifikan oleh Price Book Value, sedangkan kenaikan NPM yang semakin besar diikuti dengan penurunan yang signifikan oleh Price Book Value.

Berdasarkan kondisi Price Book Value (PBV) yang cenderung turun, maka penulis tertarik untuk mengetahui bagaimana pengaruh kinerja keuangan perusahaan yang diukur menggunakan rasio keuangan solvabilitas maupun profitabilitas dengan indikator Debt To Equity Ratio, Debt To Total Assets, Return On Assets dan Net Profit Margin 
Terhadap Price Book Value pada sektor otomotif dan komponen di BEI.

Adapun tujuan penelitian ini sebagai berikut :

1. Untuk menganalisis pengaruh Debt to Equity Ratio (DER) terhadap Price Book Value pada sektor otomotif dan komponen di Bursa Efek Indonesia Periode 2009-2013?

2. Untuk menganalisis pengaruh Debt to Assets Ratio (DAR) terhadap Price Book Value pada sektor otomotif dan komponen di Bursa Efek Indonesia Periode 2009-2013?

3. Untuk menganalisis pengaruh Return On Assets (ROA) terhadap Price Book Value pada sektor otomotif dan komponen di Bursa Efek Indonesia Periode 2009-2013?

4. Untuk menganalisis pengaruh Net Profit Margin (NPM) terhadap Price Book Value pada sektor otomotif dan komponen di Bursa Efek Indonesia Periode 2009-2013?

5. Untuk menganalisis pengaruh Debt to Equity Ratio, Debt to Assets Ratio, Return On Assets dan Net Profit Margin, secara simultan terhadap Price Book Value pada sektor otomotif dan komponen di Bursa Efek Indonesia Periode 20092013?

\section{Tinjauan Pustaka}

\subsection{Debt to Equity Ratio (DER)}

Debt to Equity Ratio menurut Harahap (2007) adalah rasio yang menggunakan hutang dan modal untuk mengukur besarnya rasio. Rasio ini digunakan untuk mengetahui jumlah dana yang disediakan oleh kreditor kepada pemilik perusahaan. Adapun rumus penghitungan DER adalah:

$$
D E R=\frac{\text { Total debt }}{\text { Shareholders'equity }}
$$

\subsection{Debt to Asset Ratio (DAR)}

Menurut Harahap (2007), Debt to Asset Ratio (DAR) adalah rasio yang menunjukkan sejauh mana utang dapat ditutupi oleh aset di mana lebih besar rasionya lebih aman (solvable). Adapun rumus penghitungan DAR adalah:

$$
D A R=\frac{\text { Total debt }}{\text { Total assets }}
$$

\subsection{Return on Asset (ROA)}

ROA merupakan alat untuk mengukur kemampuan perusahaan dalam menghasilkan keuntungan pada masa lampau untuk kemudian diproyeksikan di masa mendatang. Menurut Harahap (2007) ROA menggambarkan perputaran aset yang diukur dari penjualan. Adapun rumus penghitungan DAR adalah:

$$
R O A=\frac{\text { Net profit after taxes }}{\text { Total asset }}
$$

\subsection{Net Profit Margin}

Net Profit Margin (NPM) menurut Bastian dan Suhardjono (2006) merupakan perbandingan antara laba bersih dan penjualan. Lebih lanjut menurut Darsono dan Ashari (2005) rasio ini menggambarkan besarnya laba bersih yang diperoleh perusahaan pada setiap penjualan yang dilakukan. Adapun rumus penghitungan NPM adalah:

$$
N P M=\frac{\text { Net profit after taxes }}{\text { Net sales }}
$$

\subsection{Price Book Value}

Price to Book Value (PBV) merupakan salah satu indikator dalam menilai perusahaan. PBV menunjukkan aset bersih yang dimiliki oleh pemegang saham dengan memiliki satu lembar saham (Jugiyanto, 2003). Adapun rumus penghitungan $\mathrm{PBV}$ adalah:

$$
\begin{aligned}
& P B V \\
& =\frac{\text { price per share }}{\text { book value of equity per share }}
\end{aligned}
$$

\section{Metodologi Penelitian}




\subsection{Objek \& Lokasi Penelitian}

Objek penelitian adalah mengenai "apa yang diteliti" yaitu variabel apa yang diteliti yang terdapat dalam tema penelitian (judul). Dalam penelitian yang terdiri lebih dar/i satu variabel, maka objek penelitiannya terdiri dari variabel independen dan variabel dependen, serta keterhubungan antar variabel-variabel tersebut. Objek penelitian pada penelitian ini yaitu Kinerja Keuangan dengan indikator Debt to Equity Ratio (DER) sebagai (X1), Debt to Total Assets Ratio (DAR) sebagai (X2), Return On Assets (ROA) sebagai (X3), dan Net Profit Margin (NPM) sebagai (X4). Semuanya itu merupakan variabel bebas (Independent Variablel Variabel $\mathrm{X})$. Sedangkan sebagai variabel terikat (Dependent Variable/ Variabel Y) yaitu Nilai Perusahaan dengan indikator Price Book Value (PBV).

Lokasi penelitian adalah mengenai "di mana tempat unit analisis berada" dapat berupa organisasi/perusahaan/instansi atau daerah (wilayah, kota, kabupaten, provinsi, negara) tertentu. Lokasi penelitian pada penelitian ini yaitu Bursa Efek Indonesia (BEI).

\subsection{Jenis \& Sumber Data Penelitian}

Jenis data dalam penelitian ini adalah data kuantitatif, yaitu data berupa angka-angka yang dilihat dari neraca dan laporan laba rugi perusahaan. Sumber data dalam penelitian ini adalah data sekunder, yaitu sumber data penelitian yang diperoleh peneliti secara tidak langsung, melainkan melalui media perantara (diperoleh dan dicatat oleh pihak lain) (Indriantoro dan Supomo, 1999:147). Data sekunder ini diperoleh dari Bursa Efek Indonesia (BEI) dengan website www.idx.co.id dan Saham Oke dengan website www.sahamok.com.

\subsection{Metode Penarikan Sampel}

Penelitian ini menggunakan metode penarikan sampel yaitu purposive sampling. Menurut Sugiyono (2013:156) Purposive sampling adalah teknik penentuan sampel dengan pertimbangan tertentu. Hal yang sama diungkapkan oleh Indriantoro dan Supomo (1999:131) Purposive sampling merupakan tipe pemilihan sampel secara tidak acak yang informasinya diperoleh dengan menggunakan pertimbangan tertentu (umumnya disesuaikan dengan tujuan atau masalah penelitian).

Adapun pertimbangan tertentu yang ditetapkan untuk memperoleh sampel penelitian sebagai berikut :

1) Tercatat sebagai emiten aktif dari tahun 2009 s.d. 2013 secara terusmenerus.

2) Mengeluarkan laporan keuangan setiap tahun, dengan dasar periode tahun kalender yang berakhir tanggal 31 Desember.

3) Perusahaan yang memiliki harga saham yang $<$ Rp. 30.000

4) Perusahaan yang memiliki rata-rata hutang lebih dari satu triliun.

5) Perusahaan yang memiliki rata-rata modal sendiri lebih dari satu triliun.

\subsection{Metode Pengolahan/Analisis Data}

Setelah data yang diperlukan mengenai semua variabel penelitian terkumpul, maka data harus diolah atau dianalisis. Dalam penelitian ini alat analisis dikelompokkan dalam 2 kategori yaitu :

1. Secara Manajemen Keuangan Rasio keuangan dan Price Book Value

2. Secara Statistik

a. Deskriptif, terdiri dari :

- $\mathrm{N}$ adalah jumlah data.

- Minimum, adalah nilai terendah.

- Maximum, adalah nilai tertinggi. 
- Mean atau rata-rata.

- Standar deviation, yaitu ukuran penyebaran data dari rata-ratanya.

b. Inferensial, terdiri dari :

- Analisis regresi linier berganda

- Uji asumsi klasik

- Uji hipotesis

\section{Hasil Penelitian}

Berdasarkan hasil uji asumsi klasik dapat disimpulkan bahwa residual terdistribusi normal, tidak adanya multikolinearitas, tidak adanya heterosdastitas dan tidak adanya autokorelasi pada model regresi. Maka model regresi dapat dinyatakan baik. Persamaan regresi linier berganda untuk penelitian ini sebagai berikut:

$\mathrm{PBV}=0,990-0,294$ DER + 0,209

DAR - 3,358 ROA + 17,447 NPM

Berdasarkan persamaan tersebut dapat disimpulkan bahwa nilai konstanta (a) adalah 0,990. Artinya jika Debt To Equity Ratio, Debt To Asset Ratio, Return On Asset dan Net Profit Margin nilainya adalah nol maka Price Book Value nilainya positif 0,990 .

Nilai koefisien regresi variabel Debt To Equity Ratio (X1) bernilai negatif, yaitu -0,294. Artinya bahwa setiap peningkatan Debt To Equity Ratio sebesar 1\% maka Price Book Value juga akan menurun sebesar 0,294 dengan asumsi variabel independen lain nilainya tetap.

Nilai koefisien regresi variabel Debt To Asset Ratio (X2) bernilai positif, yaitu 0,209. Artinya bahwa setiap peningkatan Debt To Asset Ratio sebesar 1\%, maka Price Book Value juga akan meningkat sebesar 0,209 dengan asumsi variabel independen lain nilainya tetap.

Nilai koefisien regresi variabel Return On Asset (X3) bernilai negatif, yaitu $-3,233$ Artinya bahwa setiap peningkatan Return On Asset sebesar 1\%, maka Price Book Value juga akan menurun sebesar 3,233 dengan asumsi variabel independen lain nilainya tetap.

Nilai koefisien regresi variabel $\mathrm{Net}$ Profit Margin (X4) bernilai positif, yaitu 2,788. Artinya bahwa setiap peningkatan Price Book Value sebesar 1\%, maka Price Book Value akan meningkat sebesar 2,788 dengan asumsi variabel independen lain nilainya tetap.

\subsection{Pengaruh Debt To Equity Ratio, Debt To Asset Ratio, Return On Asset dan Net Profit Margin terhadap Price Book Value \\ Berdasarkan hasil uji $\mathrm{F}$ atau uji} koefisien regresi secara bersama-sama diperoleh $\mathrm{F}$ hitung > F tabel $(3,827>$ 2,69) maka Ho ditolak. Kemudian hasil tingkat signifikansi pada uji $\mathrm{F}$ kurang dari $0,05(0,013<0,05)$ maka Ho ditolak. Jadi dapat disimpulkan bahwa antara Debt To Equity Ratio, Debt To Asset Ratio, Return On Asset dan Net Profit Margin secara bersama-sama berpengaruh positif dan signifikan terhadap Price Book Value.

\subsection{Pengaruh Debt To Equity Ratio terhadap Price Book Value \\ Berdasarkan hasil uji t atau uji} koefisien regresi secara parsial diperoleh -t hitung > -t tabel $(-0,466>-1,697)$ maka Ho diterima. Kemudian hasil tingkat signifikansi pada uji t lebih dari $0,05(0,644>0,05)$ maka Ho diterima. Jadi dapat disimpulkan bahwa variabel Debt to Equity Ratio (DER) secara parsial tidak berpengaruh negatif dan tidak signifikan terhadap Price to Book Value (PBV).

\subsection{Pengaruh Debt To Asset Ratio terhadap Price Book Value \\ Berdasarkan hasil uji $\mathrm{t}$ atau uji koefisien regresi secara parsial diperoleh $\mathrm{t}$ hitung $<\mathrm{t}$ tabel $(1,361<1,697)$ maka}


Ho diterima. Kemudian hasil tingkat signifikansi pada uji t lebih dari 0,05 $(0,644>0,05)$ maka Ho diterima. Jadi dapat disimpulkan bahwa variabel Debt to Asset Ratio (DAR) secara parsial tidak berpengaruh positif dan tidak signifikan terhadap Price to Book Value (PBV).

\subsection{Pengaruh Return On Asset terhadap Price Book Value \\ Berdasarkan hasil uji $t$ atau uji} koefisien regresi secara parsial diperoleh -t hitung > - t tabel $(-3,233>-1,697)$ maka Ho ditolak. Kemudian hasil tingkat signifikansi pada uji t lebih dari 0,05 $(0,003<0,05)$ maka Ho ditolak. Jadi dapat disimpulkan bahwa variabel Return On Asset (ROA) secara parsial berpengaruh negatif dan signifikan terhadap Price to Book Value (PBV).

\subsection{Pengaruh Net Profit Margin terhadap Price Book Value}

Berdasarkan hasil uji $\mathrm{t}$ atau uji koefisien regresi secara parsial diperoleh $\mathrm{t}$ hitung $>\mathrm{t}$ tabel $(2,788>1,697)$ maka Ho ditolak. Kemudian hasil tingkat signifikansi pada uji t lebih dari 0,05 $(0,009<0,05)$ maka Ho ditolak. Jadi dapat disimpulkan bahwa variabel $\mathrm{Net}$ Profit Margin (NPM) secara parsial berpengaruh positif dan signifikan terhadap Price to Book Value (PBV).

\section{Penutup}

\subsection{Simpulan}

1) debt to equity ratio tidak berpengaruh negatif dan tidak signifikan terhadap price book value pada sektor otomotif dan komponen di Bursa Efek Indonesia (BEI) periode 2009-2013.

2) debt to asset ratio tidak berpengaruh positif dan tidak signifikan terhadap price book value pada sektor otomotif dan komponen di Bursa Efek Indonesia (BEI) periode 2009-2013.

3) return on asset berpengaruh negatif dan signifikan terhadap price book value pada sektor otomotif dan komponen di Bursa Efek Indonesia (BEI) periode 2009-2013.

4) net profit margin berpengaruh positif dan signifikan terhadap price book value pada sektor otomotif dan komponen di Bursa Efek Indonesia (BEI) periode 2009-2013.

5) debt to equity ratio, debt to asset ratio, return on asset dan net profit margin secara simultan berpengaruh dan signifikan terhadap price book value pada sektor otomotif dan komponen di Bursa Efek Indonesia (BEI) periode 2009-2013.

\subsection{Saran}

1) Bagi Perusahaan

Diharapkan dengan hasil penelitian dan simpulan yang telah diperoleh pada penelitian ini, perusahaan dapat lebih meningkatkan kinerja keuangan perusahaan guna menciptakan pertumbuhan dari tahun ke tahun. Hal ini dapat dilakukan dengan cara menyeimbangkan besarnya proporsi hutang/kewajiban dengan ekuitas perusahaan

Dengan peningkatan laba setiap tahunnya, maka akan semakin banyak orang yang menilai bahwa kinerja perusahaan dalam kondisi baik yang kemudian akan membuat mereka tertarik untuk membeli saham perusahaan sehingga harga saham pun akan mengalami kenaikan. Kinerja keuangan perusahaan itu dapat diukur dengan variabel debt to equity ratio, debt to asset ratio, return on asset dan net profit margin.

Oleh sebab itu, perusahaan harus senantiasa meningkatkan nilai rasio return on asset dan net profit margin. Hal ini ditujukan agar perusahaan dapat memberikan kepercayaan bagi pihak investor bahwa dengan meningkatnya net profit margin berarti menandakan 
perusahaan mampu menghasilkan laba yang tinggi pada tingkat penjualan tertentu. Selain itu, dengan meningkatnya return on asset menandakan perusahaan mampu menghasilkan laba tinggi setiap tahunnya dan menandakan bahwa kinerja keuangan perusahaan tersebut semakin membaik.

2) Bagi Investor

Diharapkan dengan hasil penelitian ini, pihak investor dapat dengan cerdas menganalisis debt to equity ratio, debt to asset ratio, return on asset dan net profit margin guna mengambil keputusan investasinya secara tepat. Debt to equity ratio memberikan gambaran kesehatan perusahaan melalui perbandingan antara modal sendiri dan modal pinjaman. Debt to asset ratio memberikan gambaran kesehatan perusahaan melalui perbandingan antara modal pinjaman dengan aktiva perusahaan. Return on asset memberikan gambaran efisiensi manajemen dalam menjalankan aktivanya. Net profit margin memberikan gambaran bagaimana kemampuan perusahaan menghasilkan laba pada tingkat penjualan tertentu. Sebaiknya investor memilih perusahaan dengan nilai return on asset dan net profit margin perusahaan yang positif dan mengalami kenaikan setiap tahunnya, dan memilih perusahaan dengan nilai debt to equity ratio dan debt to asset ratio yang rendah, disamping harus mempertimbangkan hal-hal penting lainnya.

3) Bagi Peneliti Selanjutnya

Dengan hasil penelitian ini, sebaiknya peneliti selanjutnya melakukan hal-hal berikut ini.

a) Dilihat dari jumlah hutang di suatu perusahaan b) Menambah variabel lain yang dapat mempengaruhi price book value

c) Periode penelitian ditambahkan dengan tahun terbaru

d) Jumlah sampel sebaiknya diperbanyak, guna membandingkan dengan penelitian lainnya.

\section{Daftar Pustaka}

Aditya Eka Laksana. 2013. Hubungan Intellectual Capital, Kinerja Keuangan Dan Nilai Perusahaan Saat IPO. Skripsi Program Ekonomika dan Bisnis Universitas Diponegoro, Semarang.

Agnes Sawir , 2005. Analisis Kinerja Keuangan Dan Perencanaan Keuangan Perusahaan. Buku 5, Edisi 1 , PT. Gramedia Pustaka Utama, Jakarta.

Agus Sartono. 2001. Manajemen Keuangan. Yogyakarta : BPFEYogyakarta.

Agus Sartono. 2012. Manajemen Keuangan : Teori dan Aplikasi. Yogyakarta : BPFE

Aries Heru Prasetyo. 2011. Valuasi Perusahaan. Edisi 1. PPM, Jakarta

Peter J. Barry and Paul N. Ellinger. 2012. Financial Management in Agriculture. 7th Edition. Upper Saddle River, NJ : Prentice Hall,

Brealey, Richard A. Stewart C. Myers, Alan J. Marcus. 2007. Fundamentals of Corporate finance. New York. The McGraw Hill.

Brealey, Richard A. Stewart C. Myers, Alan J. Marcus. 2008. DasarDasar Manajemen Keuangan Perusahaan. Jakarta: Erlangga.

Brigham, E.F. and L.C. Gapenski. 2006. Intermediate Financial Management. 7th edition. Sea Harbor Drive: The Dryden Press. 
Brigham Houston. 2010. Dasar-Dasar Manajemen Keuangan. Buku 1, Edisi 11, Salemba Empat, Jakarta.

Brownlee II, E. R., Ferris K. R. And Haskins, M. E. 2001. Corporate Financial Reporting. 4th Edition. McGraw Hill.

Catharina Anita Sulistyati. 2011. Pengaruh Kinerja Keuangan Terhadap Nilai Perusahaan Dengan Pengungkapan Corporate Social Responsibility (Csr) Sebagai Variabel Moderasi. Skripsi Program Ekonomi Universitas Atma Jaya, Yogyakarta.

D. Agus Harjito dan Martono, 2012. Manajemen Keuangan. Yogyakarta : Ekonisia.

Durrotun Nasehah, Endang Tri Widyarti. 2012. Analisis Pengaruh ROE, DER, DPR, Growth dan Firm Size terhadap Price To Book Value (PBV). Diponegoro Journal Of Management. Vol. 1 (1): hal 1-9.

Dasmon Wira. 2011. Analisis Fundamental Saham. Jakarta : Exced.

Dermawan Sjahrial. 2012. Pengantar Manajemen Keuangan. Jakarta : Edisi 4, PT. Mitra Wacana Media.

Du Toit, S. H. C., Steyn A. G. W., and Stumpf, R. H. 1981. Grapical Exploratory Data Analysis. Springer-Verlag. New York, NY.

Duwi Priyatno. 2012. Belajar Cepat Olah Data Statistik dengan SPSS 20. CV Andi Offset, Yogyakarta.

Dwi Ayuningtias. 2013. Pengaruh Profitabilitas Terhadap Nilai Perusahaan: Kebijakan Dividen Dan Kesempatan Investasi Sebagai Variabel Antara. Jurnal Ilmu dan Riset Akuntansi.Vol.1 No.1.

Dwi Prastowo dan Rifka Julianty. 2008. Analisis Laporan Keuangan. Yogyakarta: UPP-STIM YKPN.
Eva Eko Hidayati. 2012. Analisis Pengaruh DER, DPR, ROE DAN SIZE Terhadap PBV Perusahaan Manufaktur Yang Listing Di BEI Periode 2005-2007. Tesis. Universitas Diponegoro. Semarang.

Gibson, A Charles. 1992. Financial Statement Analysis. Fifth Edition. New York. South Western Publishing.

Gitman, Lawrence J. 1992. Principles of Managerial Finance, 7th Edition. Massachusetts : Addison-Wesley Publishing Company.

Farah Margaretha. 2014. Dasar-dasar Manajemen Keuangan. Buku 1. Edisi 1. PT. Dian Rakyat, Jakarta.

Handono Mardiyanto. 2009. Inti Sari Manajemen Keuangan. PT.Grasindo, Jakarta.

Helfert, Erich A. 1991. Techniques of Financial Analysis : A Guide to Value Creatio. 10th Edition. McGraw Hills

Irham Fahmi. 2012. Analisis laporan keuangan. Alfabeta. Bandung.

Jogiyanto Hartono. 2000. Teori Portofolio dan Analisis Investasi, Edisi 2, Yogyakarta: BPFE.

Kasmir. 2014. Analisis laporan keuangan. Buku 1. Edisi 7. PT.Raja Grafindo Persada, Jakarta.

Keown, Artur. J, Jhon D.Martin, J.William Petty dan David F.Scott,Jr ，2008. Manajemen Keuangan : Prinsip dan Penerapan. Buku 1. Edisi 10. PT. Indeks. Jakarta.

Novita Santi Puspita. 2011. Analisis Pengaruh Struktur Modal, Pertumbuhan Perusahaan, Ukuran Perusahaan, dan Profitabilitas terhadap Nilai Perusahaan Pada Perusahaan Manufaktur yang terdaftar di Bursa Efek Indonesia Periode 2007-2009. Skripsi 
Program Ekonomi Universitas Diponegoro, Semarang.

Nur Indriantoro dan Bambang Supomo. 1999. Metodologi Penelitian Bisnis. Yogyakarta : BPFEYogyakarta.

Prasetya Wisuda. 2010. Pengaruh Debt to Equity Ratio (DER) dan Debt to Asset Ratio (DAR) terhadap Price Book Value $(P B V)$ melalui Dividen Payout Ratio (DPR) pada perusahaan Manufaktur yang listing di BEI periode 2006-2008. Skripsi Program Ekonomi Universitas Negeri Malang, Malang.

Riahi-Belkaoui, Ahmed,Picur, Ronald D. 1998. "Multtinationality and Profitability : The Contingency of the Investment Opportunity Set". Journal of Management Finance, Vol.24, pp.3-14.

Riesa Putri Arumndati. 2009. Pengaruh EPS, NPM, ROE dan Kurs terhadap $P B V$. Skripsi Program Studi Keuangan Islam Universitas Islam Negeri Sunan Kalijaga, Yogyakarta.

Singgih Santoso. 2012. Aplikasi SPSS pada Statistik Parametik. Jakarta : PT. Alex Media Komputindo.

Sri Hermuningsih. 2011. Pengaruh Profitabilitas, Growth Opportunity, Sruktur Modal terhadap Nilai Perusahaan pada Perusahaan Publik di Indonesia. Lecturer at Economic Department, University of Sarjanawiyata Taman siswa, Yogyakarta.

Suad Husnan Dan Enny Pudjiastuti, 2012. Dasar-Dasar Manajemen
Keuangan. Buku 1, Edisi 6, Upp

Stim Ykpn, Yogyakarta.

Sugiyono. 2013. Metode Penelitian

Bisnis, CV Alfabeta, Bandung.

Sofyan Syafri Harahap, 2013. Analisis

Kritis Atas Laporan Keuangan.

Buku 10, Edisi 1, PT. Raja

Grafindo Persada, Jakarta.

Toto Prihadi. 2007. Mudah Memahami

Laporan Keuangan. Jakarta : PPM.

Van Horne, James C. dan John M.

Wachowicz, JR. 1998.

Fundamental of Financial

Management. Edisi 10. PranticeHall,Inc.

Van Horne, James C. dan John M.

Wachowicz, JR. 2007.

Fundamental of Financial

Management., Prinsip-Prinsip

Manajemen Keuangan. Jakarta :

Salemba Empat.

Weston, J. F. dan Copeland, T. E. 1996.

Manajemen Keuangan. Edisi

Sembilan. Jakarta : Penerbit Bina

Rupa Aksara.

Wild, John J. dan K.R. Subramanyam, Robert F. Halsey. 2005. Financial Statement Analysis. Buku 1. Edisi 8. Salemba Empat, Jakarta.

Zulian Yamit. 2007. Manajemen Keuangan. Buku 4, Edisi 1, Ekonisia Kampus Fakultas

Ekonomi UII, Yogyakarta.

http://rickypuspito.blogspot.com/2012/0

2/macam-macam-variabel-dalam-

penelitian.html (15 juni 2014)

http://www.idx.co.id (16 juni 2014)

http://www.sahamoke.com/emiten/sektor

-otomotif-dan-komponen/ (16 juni 2014) 